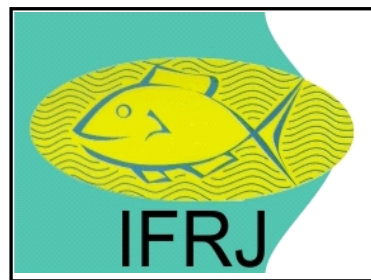

Available online at: http://ejournal-balitbang.kkp.go.id/index.php/ifrj e-mail:ifrj.puslitbangkan@gmail.com

INDONESIANFISHERIES RESEARCHJOURNAL

Volume 25 Nomor 1 June 2019

p-ISSN: 0853-8980

e-ISSN: 2502-6569

Accreditation Number RISTEKDIKTI: 21/E/KPT/2018

\title{
POTENTIALS YIELD AND FISHERIES OF MALAHAYU RESERVOIR, BREBES
}

\author{
Setiya Triharyuni¹, Aisyah ${ }^{1}$, Chaerulwan Umar $^{1}$ and Husnah ${ }^{1}$ \\ ${ }^{1}$ Research Center for Fisheries, Jln. Pasir Putih II, Ancol Timur, Jakarta Utara-14430, Indonesia \\ Received; February 02-2018 Received in revised from October 22-2018; Accepted January 07-2019
}

\begin{abstract}
Fishing activity in Malahayu Reservoir has been done since long time. Unlimited fishing may impact to the decresing of fish resources of those waters. This study presents an assessment of fishing practices in Malahayu reservoir between 2008-2016 periods. Data of potential fish production and catch per unit effort were estimated by using different estimate models, catch per unit effort was analyzed annually, while potential fish production was analyzed by using five models namely model by Henderson \& Welcome (1974), Teows \& Griffith (1979), Marshal (1984), Moreau \& De Silva (1991) and Crul (1992). The results show that changes of fish composition has accured, which was originally dominated by native fish while for now it is dominated by $72,05 \%$ of tilapia (Oreochromis niloticus) as an introduced fish. Furthermore, the average catch per unit effort (CPUE) in Malahayu reservoir is about $11,82 \mathrm{~kg}$ / fisherman, while the average potential production is about $198,55 \mathrm{~kg} /$ year. CPUE value and potential production indicate that exploitation rate in Malahayu Reservoir are in fully-exploited or perhaps over-exploited condition. Related to those conditions, not to increase the number of efforts (fishermen) as a management option towards sustainable fisheries.
\end{abstract}

Keywords: CPUE; yield; Malahayu reservoir; exploitation rate

\section{INTRODUCTION}

The reservoir is a man-made lake with various functions, namely as hydropower, irrigation, flood control, source of drinking water, tourism and fishery business (Cowx, 2002). The development of fishery reservoir business is important, because it can increase the benefits and productivity of the reservoir and also provide employment of communities around the reservoir (Triyatmo, 2001). One of the fishery reservoir activities that has grown for a long time is a fishery in Malahayu reservoir. Fisheries development in Malahayu has been done since 1984 by local fishermen who are members of Nilajaya group.

Overtime, the catch in Malahayu has been decreased. The decreased of catch is suspected as a result of the decreasing on water carrying capacity (Istiana \& Nasution, 2013) and reservoir conditions that have undergone by sedimentation (Wahyudi \& Santoso, 2002). One example of the type of fish that has decreased in catch is Mendo (Acentrogobius sp) (Soekiswo et al., 2014).

correspondence author:

e-mail: setiya.triharyuni@gmail.com
A study related to the estimation of potential fish production needs to be done to provide input in determining the policy of fish resources management in a water body in order to remain sustainable (Bramick, 2002). Various methods are used to estimate the potential of fish production in reservoirs and lakes (Moreau \& de Silva, 1991). The study of Warsa \& Purnomo (2011) states that until 2010 the condition of fishery in Malahayu Reservoir still be increased by $25 \%$. Considering the current condition of fisheries, further study is needed to know the potential yield and exploitation status at Malahayu Reservoir. Based on that interest, the purpose of this research are to study potential yield with several methods and to know the exploitation status in Malahayu Reservoir.

\section{MATERIALS AND METHODS}

9 years data from 2008-2016 that used in this paper include of catch, number of fishermen and type of fishing gear. Those data was obtained from the enumerator funded by the Research Center for Recovery of Fish Resources (Balai Riset Pemulihan 
Sumberdaya Ikan, Jatiluhur). While catch data, number of fishermen, types of fishing gear and catch composition from 2014-2016 was based on the existing record in Nilajaya fishing group, in Malahayu Reservoir, Brebes, Central Java.

\section{Fish Potential Yield}

The fish potential yield of the reservoir is estimated by using the Morpho-Edaphic Index (MEI) model and the reservoir area. The conductivity data used is derived from the measurements in the previous study. Method of estimation of potential production used in this research covers:

\section{$1^{\text {st }}$ Model (Henderson \& Welcome, 1974):}

$Y=14,3136 M^{0,4681}$

Where, $\mathrm{Y}$ is potency ( $\mathrm{kg} / \mathrm{ha} /$ year) and $\mathrm{MEI}$ is Morpho-Edaphic Index. MEl is calculated by the equation as follows:

$M E I=\frac{\text { conductivity }}{\text { average depth }}$

$2^{\text {nd }}$ Model (Teows \& Griffith, 1979):

$\log (Y)=1,4071+0,3697 \log (M E I)-0,00004565 A_{0} \cdots$

$3^{\text {rd }}$ Model (Marshall, 1984):

$\ln \left(Y_{t}\right)=3,57+0,76 \ln \left(A_{0}\right)$

$4^{\text {th }}$ Model (Moreau \& De Silva, 1991):

$Y=436,2+0,336 A+0,745 E$

$5^{\text {th }}$ Model (Crul, 1992):

$Y_{t}=8,32 A_{0}^{0,92}$
Where, A reservoir area in ha, E fishing effort (number of fishermen), $Y_{t}$ total potency (ton/year) and $A_{0}$ reservoir area in $\mathrm{km}^{2}$.

\section{Catch Rate}

Catch per unit effort (CPUE) often called as catch rate, that is in this study expressed as number of fish caught by each fishermen (kg/fisherman). All fishermen carrying out fishing are calculated to estimate total fishing efforts. Total catch can be estimated by multiplying the value of CPUE by the effort (Stamatopoulos, 2002). Based on this, then the calculation of CPUE calculated by the equation as follows:

$$
\text { CPUE }=\frac{c}{f}
$$

Where, CPUE is the catch per unit effort, $\mathrm{C}$ is the number of catch and $f$ is fishing effort.

\section{RESULT AND DISCUSSION \\ Results}

\section{Catch Composition}

The fish species caught by fishermen in Malahayu Reservoir consists of Oreochromis niloticus (nile tilapia), Channa striata (striped snakehead), Mystus nigriceps (two spot catfish), Acentrogobius sp (mendo fish), Cyprinus carpio (common carp), Pangasianodon hypophthalmus (striped catfish), Rasbora argyrotaenia (silver rasbora), Trichogaster pectoralis (snake skin gouramy) and Monopterus albus (Asian swamp eel). Beside fish also caught type of shrimp (Macrobrachium spp). The average of catch during $2008-2016$ is dominated by $72,05 \%$ of tilapia fish, followed by $8,62 \%$ of striped snakehead, $4,81 \%$ of shrimp, $2,52 \%$ of catfish, $2,10 \%$ of mendo fish and $0,34 \%$ of two spot catfish (Figure 1).

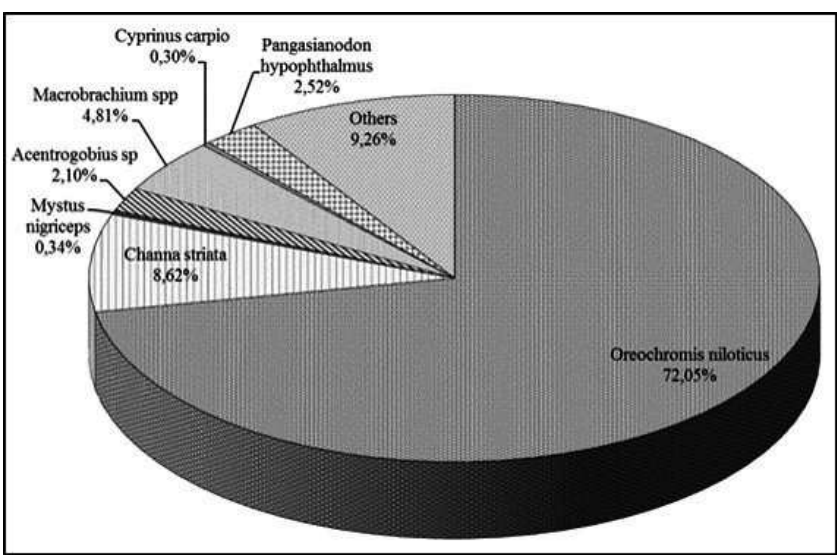

Figure 1. Catch composition in Malahayu Reservoir. 


\section{Potential Fish Production}

In calculating the potential production of Malahayu Reservoir, several parameters like reservoir area, average depth and conductivity are used in all of five models (Tabel 1 ).

Estimation model of potential production in Malahayu Reservoir produce potential value of reservoir production equal to $46,10-1189,75 \mathrm{~kg}$ / ha / year or $28,58-737,65$ ton/year. Then the average of potential fish in Malahayu Reservoir is 198,55 ton/year or 320,25 $\mathrm{kg} / \mathrm{ha} /$ year (Table 2). The average of potential production is lower than potential production in 2010 which is reach to 828 tons/year (Warsa \& Purnomo, 2011). Comparison of model usage show that Moreau \& De Silva (1991) generates highest potential production estimation than other model used in this study or equal to 737,65 ton/year, while Henderson \& Welcome (1974) model generates the lowest potential production estimation or equal to 28,58 ton/year.

Table 1. Input parameters used in estimating the potential yield of fish in Malahayu Reservoir

\begin{tabular}{cccc}
\hline Reservoir & Area $\left(\mathbf{k m}^{2}\right) /$ & Depth $(\mathbf{m})$ & Conductivity $(\mathbf{u S} / \mathbf{c m})$ \\
\hline Malahayu & $6,2^{*}$ & $2,47^{\star \star}$ & $30,05^{\star \star \star}$
\end{tabular}

Source: ") Warsa \& Purnomo, 2011; " Fahmi \& Santosa, 2014; "*) Andriyanto et al., 2012

Table 2. Potential fish yield estimates for Malahayu Reservoir

\begin{tabular}{clcc}
\hline No. & \multicolumn{1}{c}{ Models } & Productivity (Kg/ha/year) & Potential Yield (ton/year) \\
\hline 1 & Henderson \& Welcome (1974) & 46,10 & 28,58 \\
2 & Teows \& Griffith (1979) & 64,27 & 39,85 \\
3 & Marshal (1984) & 292,22 & 142,17 \\
4 & Moreau \& De Silva (1991) & 1189,75 & 737,65 \\
5 & Crul (1992) & 71,90 & 44,58 \\
\hline \multicolumn{2}{c}{ Average } & 320,25 & 198,55 \\
\hline
\end{tabular}

\section{CPUE of Malahayu Reservoir}

Fish production in Malahayu Reservoir tends to decrease during 2009-2012 respectively, on the other hand there is an increase of the production in 2013-2016. Both periods analysis obtained that average production of $2008-2016$ about 150,23 tons (Figure 2).

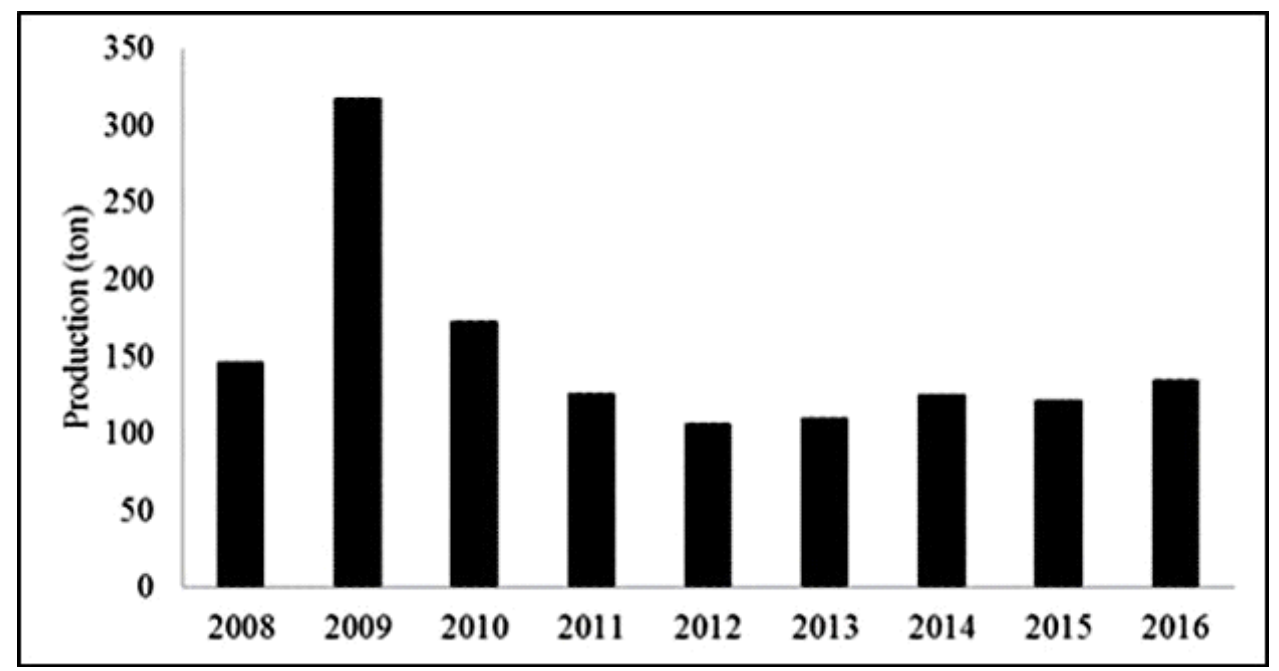

Figure 2. Fish production of Malahayu Reservoir in 2008-2016.

Malahayu fisherman are the people who live and utilize the reservoir resources, the community comes from five villages that are Malahayu village, Cawiri, Kracak, Rembet and Dukuh Jati village. Fisherman are grouped into a group namely Nilajaya, whose institutions have been legally valid in 2016. Total amount of fisherman reach to 129 people which the largest number of fishermen came from Cawiri area and the least was from Rembet (Figure 3). 


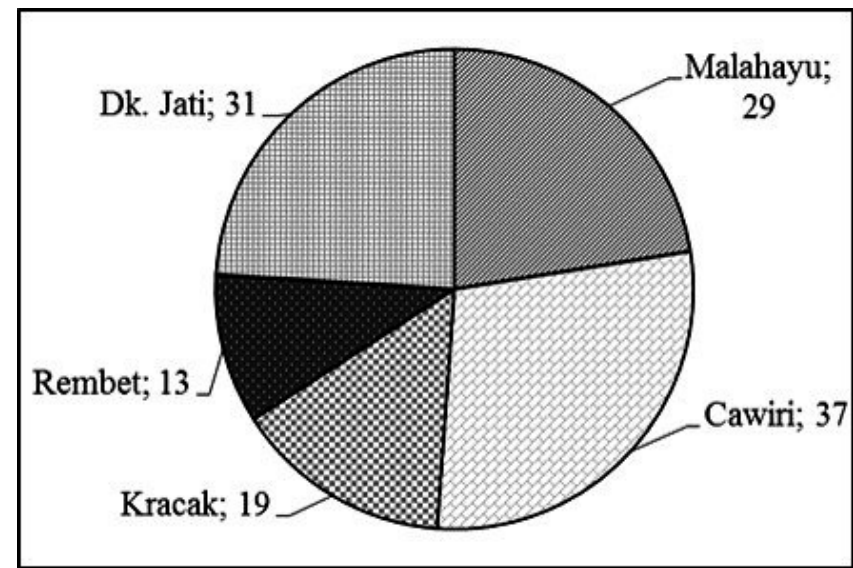

Figure 3. Numbers of fisherman of Malahayu Reservoir in 2017.

Fishing activity in Malahayu is quite intensive, based on interviews with local fishermen it is known that fishing activities are carried out throughout the day (Triharyuni et al., 2017). A relatively high intensity level is indicated by the downward trend in CPUE values in 2008-2016. The average value of CPUE in Malahayu Reservoir is $11,82 \mathrm{~kg} /$ fisherman (Figure 4). This value is higher than in Warsa \& Purnomo (2011), by using a monthly data period during 2010 they obtained CPUE aqual to $5,8 \mathrm{~kg} /$ fisherman.
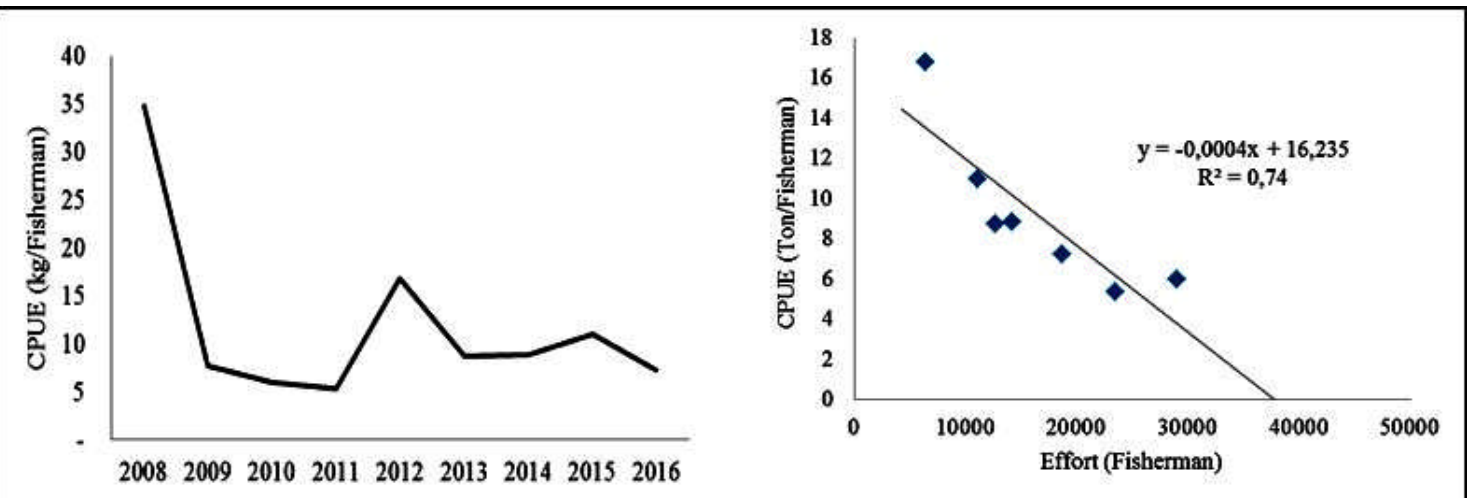

Figure 4. Annually trend of CPUE (a) and CPUE and fishing effort relationship of Malahayu Reservoir in 2008-2016.

The relationship between effort and CPUE generates an equation CPUE $=-0,0004 f+16,235$ (Figure 4). Those equation produced the value of sustainable yield (MSY) of 164,74 tons and 20 thousand fishermen as the effort of catch. Data show that catch production

in 2016 is about 135,7 tons, then the exploitation rate is equivalent to $68 \%$ of its potential production or $82 \%$ of MSY (Figure 5). The exploitation rate of fish in Malahayu Reservoir is categorized as fullyexploited.

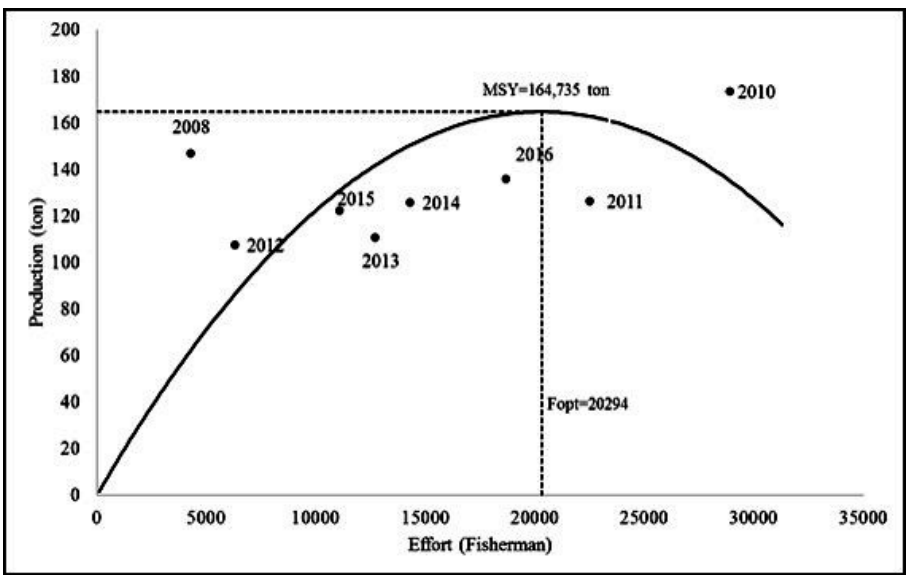

Figure 5. Comparison between actual catch, fishing effort and MSY. 


\section{Discussion}

Fish species contained in Malahayu Reservoir consists of native/indigenous and introduced fish species (Kartamihardja et al., 2011). Native species such as Puntius binotatus, Mystus nigriceps and Macrognathus aculeatus, while the introduced species such as Oreochromis mossambicus, O. Niloticus, Channa striata, Pangasianodon hypophthalmus and Trichogaster pectoralis. Fish species in the Malahayu Reservoir are more varied when compared with previous research (Warsa \& Purnomo, 2011). The more varied species of fish is due to the fish stocking programme in Malahayu reservoir either done intentionally or not.

Calculation of potential fish production in Malahayu Reservoir shows lower value from result of previous research by Warsa \& Purnomo (2011), that is 1337 $\mathrm{kg} / \mathrm{ha} /$ year or 828 ton/year. The average productivity of Malahayu Reservoir is about 198,55 tons/year, this value is also relatively lower when compared to productivity in other reservoirs. The potential production in the Darma Reservoir reaches 359-450 tons/year with flood area 400 ha (Tjahyo, 2000), and 237-307 ton/tahun in Sempor Reservoir with maximum water surface area 275 ha (Purnomo et al., 2013), while River Basin Authority of Serayu-Opak stated that catchment area of Sempor Reservoir is $43 \mathrm{~km}^{2}$. The potential production of Malahayu also lower than reservoirs in Africa which has a potential production of $329 \mathrm{~kg} / \mathrm{ha} / \mathrm{year}$, higher than reservoir in the United States and the Caribbean that is only reached $125 \mathrm{~kg} / \mathrm{ha} /$ year (SOFIA, 2002) and Ethiopia which is only $66,6 \mathrm{~kg} / \mathrm{ha} /$ year (Teame et al., 2016). Those conditions show that the potential production of reservoirs does not depend on the area. High or low potential value means a description of the dynamics of fish resources in the reservoir and also the condition of the aquatic habitat (Anna, 2016).

Decreasing in potential production is suspected not only due to fishing pressure but also by a decrease in environmental quality. Malahayu Reservoir as stated in Wahyudi \& Santoso (2002), has experienced habitat degradation due to sedimentation and environmental quality. The exploitation rate (ER) are classified into three, namely (1) moderate, with a range of values of $E R \leq 0,5$; (2) fully-exploited, $0,5<E R \leq 1,0$; dan (3) overfishing, ER>1,0 (Suman, 2016). So that the exploitation rate in Malahayu Reservoir based on those classification has reached about $82 \%$ or 0,82 , or it can be said that the condition of fisheries in Malahayu Reservoir is categorized as fully-exploited. Those condition is contrasts with Kantoussan et al. (2014) who states that the status of fisheries with a decreasing CPUE and reservoir potential fish production, indicates over-exploitation. Declines in CPUE may means that the fish population cannot support the level of harvesting (Stamatopoulos, 2002). This condition is much different in the period of 20092010, where is the exploitation rate in Malahayu Reservoir is under-exploited, or still have an opportunity to increase up to $25 \%$ (Warsa \& Purnomo, 2011).

Based on the condition of capture fisheries that was already in fully-exploited to over-exploited, it requires a certain effort to lead to sustainable capture fisheries, that is by setting the input and output in the fisheries (Fauzi, 2010; Anna, 2010; Anna, 2016). One of the policy implementation that can be done is input restriction, which is in this case is fishing effort (Anna, 2016). Or in other words, there should be no additional number of fishermen in Malahayu Reservoir.

On the other hand, to increase the number of stocks, one of the efforts that can be done is to conduct stocking of fish that has a rapid development and appropriate with the water environment of reservoirs (Lorenzen et al., 2001; Warsa \& Purnomo, 2011 ; Ingram \& De-Silva, 2015). Fish introduction is the most commonly used for increasing fish production in reservoir or lake waters (Moreau \& De Silva, 1991). The increase in production of a stocking programme has been seen in several reservoirs in Sri Lanka, so the catch becomes increased by 42,8 134\% (Pushpalatha \& Chandrasoma, 2010).

\section{CONCLUSION}

The average productivity of Malahayu Reservoir is about 198,55 tons/year, average value of CPUE is $11,82 \mathrm{~kg} /$ fisherman and MSY of 164,74 tons. Exploitation rate is $82 \%$ of MSY indicating at fullyexploited stage even towards over-exploited. Policy implementation that can be done is input restriction (number of fishermen).

\section{ACKNOWLEDGEMENTS}

This paper is a part of contribution in study on "policy brief of fish production enhancement in reservoir of Java", through DIPA 2017 under the Research Center for Fisheries. Authors would like to say thank you to Prof. Endi S. Kartamihardja for the valuable and constructive comments during the project. We wish also to extend our gratitude to the many officials in all relevant local government institutions particularly the Brebes District Marine and Affairs and Fisheries Services and chairman of the fishermen group Nilajaya for supporting data during the project activities. 


\section{REFERENCES}

Andriyanto, S., Tahapari, E., \& Insan, I. (2012). Nursery management of catfish in outdoor pool to produce seeds in Malahayu reservoir, Brebes, Central Java. Media Akuakultur, 7(10), 20-25. DOI: http://dx.doi.org/10.15578/ma.7.1.2012.20-25

Anna, Z. (2016). Sustainable capture fishery management in the Cirata reservoir: a bio-economic modelling approach. J. Sosek KP, 11(2), 161-172. DOI: http://dx.doi.org/10.15578/isekp.v11i2.3688

Crul, R.C.M. (1992). Models for estimating potential fish yields of African inland waters. CIFA Occasional Paper. No. 16. Rome, FAO. 22p.

Bramick. U. (2002). Estimation of the fish yield potentialof lake in north-east Germany. Edited by Cowxl. G. Management and Ecology of lake and reservoir fisheries. Blackwell Science. lowa. $26-$ 33.

Fahmi, Z., \& Sentosa, A. A. (2014). Morfometry characteristics and estimation of fish density in Malahayu reservoir using hidroacoustic method. Proceeding of Indonesian Fisheries National Seminar, held on November, 20-21, 2014, 389-396.

Henderson, H.F., \& Welcomme, R. L. (1974). The relationship of yield to morphoedaphic index and numbers of fishermen in African inland fisheries. CIFA Occasional Paper, 119.

Ingram, B. A., \& De-Silva, S. (2015). General aspect of stock enhancement in fisheries developments. Paper downloaded in pdf version, p.11.

Istiana \& Nasution, Z. (2013). Diffusi of institutional enhancement capacities on fisheries resource management (Case studies in reservoir Malahayu, Brebes, Central Java). Buletin Riset Sosek Kelautan dan Perikanan, 8(1), 25-29.

Kartamihardja, E, S., Purnomo, K., Koeshendrajana, S., \& Prisantoso, B.I. (2011). Co-management guidance of Culture Based Fisheries (CBF) at Malahayu Reservoir, Brebes Regency, Central Java. Research Center for Fisheries Management and Conservation, p. 29.

Kantoussan, J., Ecoutin, J.M., Fontenelle, G., de Morais, L.T., \& Lae, R. (2014). Catch per unit effort and yields as indicators of exploited fish communities: application to two West African reservoirs. Lakes and Reservoirs: Research and Management, 19, 86-97.

Lorenzen, K., Amarasinghe, U.S., Bartley, D.M., Bell, J.D., Bilio, M., de Silva, S.S., Garaway, C.J.,............Swar, D.B. (2001). Strategic Review of enhancements and culture-based fisheries. In R.P. Subasinghe, P. Bueno, M.J. Phillips, C. Hough, \& S.E. McGladdery (Eds). Aquaculture in the Third Millennium. Technical Proceedings of the Conference on Aquaculture in the Third Millennium, Bangkok, Thailand, 20-25 February 2000. pp. 221237.

Marshall, B. E. (1984). The role of limnology in fisheries management in Zimbabwe, Verh. Int. Verein. Theor. Angew. Limnol, 22, 2671-2675.

Moreau, J., \& De Silva, S, S. (1991). Predictive fish yield models for lakes and reservoirs of the Philipines, Sri Lanka and Thailand. FAO Fish. Tech. p. 319.

Purnomo K., Kartamihardja, E.S., Nurfiarini, A., \& Nasution, Z. (2009). Research on culture based fisheries, CBF in reservoirs/lakes in West of Java and Central Java. Research Center for Capture Fisheries (Unpublished report). p.47.

Purnomo, K., Warsa, A., \& Kartamihardja, E.S. (2013). Carrying capacity and potential fish production in Sempor reservoir, Kebumen District, Central Java. J.Lit.Perikan.Ind, 19(4), 203-212. DOI: http:// dx.doi.org/10.15578/ippi.19.4.2013.203-212

Pushpalatha, K. B. C., \& Chandrasoma, J. (2010). Culture-based fisheries in minor perenial reservoirs in Sri Lanka: Variability in production, stocked species and yield implication. J. Appl. Ichthyo, I26, $99-104$.

Soekiswo, Y.A., Widyorini, N., \& Solichin, A. (2014). Biological aspect of mendo fish (Acentrogobius $\mathrm{sp})$ in Malahayu reservoir, Brebes District. Diponegoro Journal of Maquares, 3(4), 154-160.

Suman, A. (2016). Potency and exploitation rate of fish resources in Indonesia Fisheries Management 2015. Paper presented of National Committee of Fish Stock Assessesment. Marine and Fisheries Research Institute.

Stamatopoulos, C. (2002). Sample-based fishery surveys - a technical handbook. FAO Fisheries Technical Paper. No. 425. Rome, FAO, p. 132. 
Tjahyo, D. W.H. (2000). Biolimnological and potential fish production in Darma reservoir, West Java. J.Lit.Perik.Ind, 6 (3-4), 10-23. DOI: http:// dx.doi.org/10.15578/ippi.6.3-4.2000.10-23.

Teame, T., Natarajan, P., \& Tesfay, Z. (2016). Assessment of fishery activities for enhanced management and improved fish production in Tekeze reservoir, Ethiopia. International Journal of Fauna and Biological Studies, 3(1), 105-113.

Triharyuni, S., Husnah., Kartamihardja, E.S. , Umar, C., \& Aisyah. (2017). Policy brief of fish production enhancement in reservoir of Java. Research Center for Fisheries. Final report. p. 86.
Triyatmo, B. (2001). Study of limnological condition of Sermo reservoir on pra-Inundation. Jurnal Perikanan UGM III, (2), 1-9.

Warsa, A., \& Purnomo, K. (2011). Estimation of the fish potential yield and state of fisheries of Malahayu Reservoir, Brebes Regency, Central Java Province. J. Lit. Perikan. Ind, 17(4), 237-245. DOI: http://dx.doi.org/10.15578/ ippi.17.4.2011.237-245

Wahyudi, S.I., \& Santoso, E. (2002). Re-study on operational guidlines and echosounding measurement of Malahayu reservoir. Colaborative final report of Management of Water Resources Services, Central Java and Unisula Semarang. 